JURNAL NOMINAL / VOLUME III NOMOR 1 / TAHUN 2014

\title{
PENGARUH NEGATIVE FRAMING DAN ADVERSE SELECTION TERHADAP ESKALASI KOMITMEN
}

\author{
Muhammad Sandi Arimawan \\ Alumni Prodi Akuntansi Fakultas Ekonomi Universitas Negeri Yogyakarta \\ Muhammad_sandi21@yahoo.com
}

Sukirno

Jurusan Pendidikan Akuntansi Universitas Negeri Yogyakarta

\begin{abstract}
Abstrak: Pengaruh Negative Framing dan Adverse Selection terhadap Eskalasi Komitmen. Penelitian ini dilakukan bertujuan untuk mengetahui: (1) Pengaruh negative framing terhadap eskalasi komitmen, (2) Pengaruh adverse selection terhadap eskalasi komitmen, (3) Pengaruh negative framing dan adverse selection secara bersama-sama terhadap eskalasi komitmen, (4) Pengaruh negative framing terhadap eskalasi komitmen dimoderasi locus of control, (5) Pengaruh adverse selection terhadap eskalasi komitmen dimoderasi locus of control, (6) Pengaruh negative framing dan adverse selection secara bersama-sama terhadap eskalasi komitmen dimoderasi locus of control. Penelitian ini termasuk ke dalam penelitian eksperimen dengan desain eksperimen factorial $2 \times 2$ beetwen subject. Populasi pada penelitian ini adalah mahasiswa sebagai pengganti manager yang sesunguhnya dengan jumlah populasi adalah 171 mahasiswa dari 2 kelas Pendidikan Akuntansi angkatan 2010 dan 2 kelas Akuntansi angkatan 2011. Teknik untuk pengambilan sampel digunakan metode Gay (1992). Sebelum penelitian yang sesungguhnya, dilakukan pilot test untuk mengetahui apakah kasus yang akan digunakan dapat dimengerti subjek atau tidak. Alat uji yang digunakan dengan menggunakan uji prasyarat analisis yang meliputi uji normalitas dan uji homogenitas. Metode analisis data yang digunakan adalah analisis two ways anova. Hasil dari penelitian ini adalah: (1) negative framing terbukti berpengaruh terhadap eskalasi komitmen, hal ini ditunjukan dengan $\mathrm{P}_{\text {value }}$ signifikan $0,000(<0,05),(2)$ adverse selection terbukti berpengaruh terhadap eskalasi komitmen, hal ini ditunjukan dengan $\mathrm{P}_{\text {value }}$ signifikan $0,000(<0,05)$, (3) negative framing dan adverse selection secara bersama-sama terbukti berpengaruh terhadap eskalasi komitmen, hal ini ditunjukan dengan $\mathrm{P}_{\text {value }}$ signifikan $0,000(<0,05)$, (4) pengaruh negative framing terhadap eskalasi komitmen tidak terbukti dimoderasi locus of control, hal ini ditunjukan dengan $\mathrm{P}_{\text {value }}$ signifikan 0,926 $(>0,05),(5)$ pengaruh adverse selection terhadap eskalasi komitmen tidak terbukti dimoderasi locus of control, hal ini ditunjukan dengan $\mathrm{P}_{\text {value }}$ signifikan 0,462 (>0,05), (6) pengaruh negative framing terhadap eskalasi komitmen terbukti dimoderasi locus of control, hal ini ditunjukan dengan $\mathrm{P}_{\text {value }}$ signifikan $0,007(<0,05)$.
\end{abstract}

Kata Kunci : Adverse selection, Negatif Framing, Locus of control, Eskalasi Komitmen, Pengambilan keputusan.

Abstract: The Influence of Negative Framing and Adverse Selection toward Commitment Escalation. The aim of this research is to find empirical proof about : (1) the influence of negative framing to escalating commitment, (2) the influence of adverse selection to escalating commitment, (3) the influence of negative framing and adverse selection as one to escalating commitment, (4) the influence of locus of control as moderating variable in the influence of negative framing to escalating commitment, (5) the influence of locus of control 
as moderating variable in the influence of adverse selection to escalating commitment, (6) the influence of negative framing and adverse selection as one to escalating commitment moderated by locus of control.This research belongs to experimental research usingresearch design factorial $2 \times 2$ between subject. The population of this research is students as substitution of the real manager. 171 respondent participation from 2 classes of Accounting Education major class of 2010, and 2 classes of Accounting major class of 2011. Sample collection technique used Gay method (1992). The full-scale study would be done after doing pilot test to know how far respondent participation understands about the cases. This research use normality test and homogeneity test as prerequisite testanalysis. The analysis method of this research used two ways ANNOVA analysis.The results show that: (1) negative framing has significant influence to escalating commitment $\left(P_{\text {value }} 0,000<0,05\right),(2)$ adverse selection has significant influence to escalating commitment $(P$ value $0,000<0,05)$, (3) negative framing and adverse selection as on have significant influence to escalating commitment $\left(P_{\text {value }} 0,000<0,05\right)$, (4) locus of control as moderating variable can't moderate in the influence of negative framing to escalating commitment $\left(P_{\text {value }} 0,926>0,05\right)$, (5) locus of control as moderating variable can't moderate in the influence of adverse selection to escalating commitment $(P$ value $0,462>0,05)(6)$ locus of control as moderating variable can moderate in the influence of negative framing to escalating commitment, it shows significant influences $\left(P_{\text {value }} 0,007<0,05\right)$.

Key Words : Adverse selection, Negative Framing, Locus of Control, Escalating Commitment, Decision Making

\section{PENDAHULUAN}

Seiring dengan perkembangan dunia perekonomian dewasa ini, anggaran adalah salah satu hal yang penting yang harus dibuat oleh seorang manager keuangan untuk memulai suatu kegiatan bisnis yang dijalankan perusahaan. Anggaran adalah suatu rencana kuantitatif periodik yang disusun berdasarkan program yang telah disahkan dan umumnya dinyatakan dalam satuan uang akan tetapi dapat juga dalam satuan barang atau jasa. Anggaran merupakan sebuah hasil dari suatu proses penyusunan anggaran, sedangkan proses dalam penyusunan anggaran disebut sebagai penganggaran. Penganggaran modal sering disebut sebagai pengeluaran modal atau penggunaan dana untuk menyediakan harta operasi yang akan menolong untuk mendapatkan pendapatan di masa mendatang atau mengurangi biaya masa datang.

Penganggaran modal sama halnya melakukan suatu kegiatan investasi, sebagai konsekuensinya dari tindakan investasi tersebut, sebuah perusahaan membutuhkan prosedur atau proses tertentu untuk menganalisa dan menyeleksi beberapa alternatif yang ada untuk membuat suatu keputusan investasi.

Menurut Gunawan Adisaputro (1997: 39), keputusan tentang pemilihan investasi merupakan keputusan yang paling penting diantara keputusan lainnya yang yang harus diambil oleh seorang manager. Pengambilan keputusan akan menjadi suatu indikator 


\section{JURNAL NOMINAL / VOLUME III NOMOR 1 / TAHUN 2014}

pengukuran keberhasilan atau kegagalan seorang manager.

Akan tetapi, seorang manager seringkali mempunyai rasa ikatan emosional yang kuat dengan keputusan yang dibuat sebelumnya, sehingga manager tersebut mempunyai kesulitan dalam memisahkan keputusan yang diambil sebelumnya dengan keputusan yang berhubungan dengan masa depan (Bazerman dalam Tri Koroy Ramaraya, 2008), dan manager tersebut akan cenderung meningkatkan komitmennya bila mendapat suatu informasi negatif (kerugian) dari proyek investasi yang ditanganinya. Fenomena manager meningkatkan komitmennya tersebut dapat dikatakan sebagai suatu fenomena eskalasi komitmen. Dikatakan eskalasi komitmen karena manager tersebut cenderung tetap melanjutkan proyek investasinya walaupun proyek tersebut tidak menghasilkan laba yang signifikan atau proyek tersebut mengindikasikan kegagalan.

Teori keagenan (agency theory) memberi penjelasan mengenai eskalasi komitmen dengan memprediksi bahwa ketidakseimbangan informasi yang terjadi antara principal (pemilik) dengan agent (manager) akan mempengaruhi keputusan yang dibuat oleh manager tersebut. Salah satu masalah yang dapat ditimbulkan dari suatu ketidakseimbangan informasi adalah adverse selection. Adverse selection dapat diartikan sebagai keadaan adanya ketidakseimbangan informasi antara pemilik dan manager dan manager tersebut memiliki kesempatan untuk melalaikan tugas (incentive to shirk), dan pada akhirnya keputusan yang dibut manager tersebut akan menguntungkan dirinya saja.

Berbeda dengan teori keagenan, teori propek (prospect theory) memberi penjelasan mengenai eskalasi komitmen sebagai akibat dari pembingkaian (framing) yang diterima oleh oleh manager tersebut, dan framing informasi tersebut dapat mempengaruhi suatu keputusan yang dibuat oleh seorang manager. Menurut bateman dan Zeithhaml (1989) serta White (1986) dalam Tri Koroy Ramaraya (2008), dalam konteks keputusan investasi, seorang manager yang menerima umpan balik negatif (negative framing) atas keputusan investasi yang dibuat sebelumnya akan berada pada posisi rugi, dan akan memandang keputusan berikutnya sebagai pilihan antara kerugian yang pasti yang sudah terjadi dan kerugian di masa mendatang yang kurang pasti. Dalam hal ini, manager cenderung untuk mengambil risiko dengan memilih kerugian di masa mendatang yang kurang pasti dengan komitmen manambah dana untuk menyelamatkan proyek investasinya dan berharap mendapat keuntungan di masa yang akan datang.

Mengenai penelitian tentang negative framing, adverse selection dan pengaruhnya 


\section{JURNAL NOMINAL / VOLUME III NOMOR 1 / TAHUN 2014}

terhadap eskalasi komitmen, terdapat perbedaan hasil penelitian dari penelitianpenelitian terdahulu. Hal inilah yang membuat peneliti berkeinginan menguji kembali dengan variabel yang sama, teori yang sama, dan subjek yang sama akan mendapat hasil yang sama atau justru malah berbeda.

Penelitian ini juga melakukan modifikasi penelitian dengan menambahkan suatu variabel pemoderasi yaitu locus of control, yang bertujuan untuk mengetahui apakah locus of control memoderasi pengaruh negative framing, adverse selection, serta negative framing dan adverse selection secara bersama-sama terhadap eskalasi komitmen.

Konsep locus of control pertama kali diperkenalkan oleh Julian B. Rotter (1996), seorang ahli teori pembelajaran sosial. Locus of control merupakan kendali individu atas pekerjaan mereka dan kepercayaan mereka terhadap keberhasilan diri. Ada 2 tipe locus of control, yaitu internal locus of control dan eksternal locus of control. Internal locus of control adalah seseorang yang percaya bahwa keberhasilan bersumber dari kemampuan dalam dirinya, sedangkan eksternal locus of control adalah seseorang yang percaya bahwa keberhasilan ditentukan oleh orang lain, takdir, dan faktor lain diluar dirinya.

Andi Irfan (2009) dalam penelitiannya mengatakan bahwa manager yang memiliki tipe eksternal locus of control cenderung memiliki tingkat sensitifitas tinggi, sedangkan manager yang memiliki memiliki tipe internal locus of control cenderung memiliki tingkat sensitifitas yang rendah. Jadi, apabila seorang manager bertipe eksternal locus of control yang memiliki tingkat sensnitifitas tinggi dihadapkan pada suatu kondisi negative framing dan adverse selection atas proyek investasinya, maka manager tersebut cenderung akan menurunkan eskalasi komitmen, sedangkan manager yang bertipe internal locus of control yang memiliki tingkat sensitifitas rendah diperlakukan dengan hal yang sama, maka manager tersebut cenderung meningkatkan eskalsasi komitmen.

Dari penjelasan-penjelasan sebelumnya mengenai penganggaran modal, pengambilan keputusan, eskalasi komitmen, negative framing, adverse selection, dan locus of control, maka penelitian ini akan membahas tentang "Pengaruh Negative Framming dan Adverse Selection terhadap Eskalasi Komitmen dalam Pengambilan Keputusan Penganggaran Modal untuk Investasi dengan Locus Of Control sebagai Variabel Pemoderasi”.

\section{METODE PENELITIAN}

\section{Jenis dan Desain Penelitian}

Penelitian ini termasuk ke dalam bentuk penelitian eksperimen. Jenis penelitiannya adalah penelitian eksperimen factorial 


\section{JURNAL NOMINAL / VOLUME III NOMOR 1 / TAHUN 2014}

lengkap seimbang dan rancangan eksperimennya adalah eksperimen acak lengkap. Desain ekperimen yang digunakan dalam penelitian ini adalah desain eksperimen faktorial 2x2 between subject.

Tabel 1. Desain Faktorial 2x2

\begin{tabular}{lllr}
\hline & & \multicolumn{2}{c}{ Adverse Selection } \\
& & Ada & Tanpa \\
Negative & Ada & Kasus A & Kasus C \\
Framing & Tanpa & Kasus B & Kasus D \\
\hline
\end{tabular}

Sumber: Data diolah.

\section{Definisi Operasional Variabel}

Definisi eskalasi komitmen adalah kecenderungan untuk bertahan pada tindakan yang tidak efektif untuk jangka waktu yang lama. Pengukuran variabel eskalasi komitmen dengan skala keputusan 1 sampai dengan 6. Skala 1 adalah untuk menghentikan dan skala 6 untuk melanjutkan

Negative framing adalah sebuah pengemasan suatu informasi yang lebih diperlihatkan sisi negatifnya, seperti halnya suatu kerugian. Pengukuran variabel negative framing adalah dengan memberi skor 1 untuk perlakuan ada negative framing dan skor 0 untuk perlakuan tanpa negative framing.

Adverse selection adalah sebuah kondisi di mana antara pemilik dan manager terjadi ketidakseimbangan informasi dan terdapat kesempatan melalikan tugas bagi manager.
Pengukuran variabel adverse selection adalah dengan memberi skor 1 untuk perlakuan ada adverse selection dan skor 0 untuk perlakuan tanpa adverse selection.

Locus of control merupakan kendali individu atas seuatu pekerjaan mereka dan kepercayaan mereka terhadap keberhasilan diri. Ada 2 jenis locus of control, yaitu eksternal locus of control (percaya akan faktor dari luar diri) dan internal locus of control (percaya pada kemampuan diri sendiri). Pengukuran variabel locus of control dengan 5 poin skala likert. Pengukuran tipe locus of control, dengan melihat mean score, lebih dari mean score bertipe eksternal locus of control dan diberi skor 1, sedangkan kurang dari mean score bertipe internal locus of control dan diberi skor 0 .

\section{Subjek Penelitian}

Subjek penelitian pada penelitian ini adalah mahasiswa Fakultas Ekonomi Universitas Negeri Yogyakarta program studi Pendidikan Akuntansi angkatan 2010 dan Akuntansi angkatan 2011. Jumlah subjek keseluruhan sebanyak 156 orang, yang terdiri dari 48 orang kelas A dan 47 orang kelas B untuk program studi Pendidikan Akuntansi angkatan 2010, sedangkan untuk program studi Akuntansi angkatan 2011 terdiri dari 44 orang kelas A dan 32 orang kelas B. Teknik penetapan kriteria subjek yang digunakan adalah 


\section{JURNAL NOMINAL / VOLUME III NOMOR 1 / TAHUN 2014}

purposive sampling. Untuk menentukan ukuran atau banyaknya subjek yang digunakan adalah dengan metode Gay (1992) dalam Gendro Wiyono (2011: 86) yang menyebutkan bahwa untuk penelitian eksperimental dapat menggunakan data minimal sejumlah 15 subjek per kasus.

\section{Prosedur}

Penelitian eksperimen ini dilakukan pada 2 kelas program studi pendidikan akuntansi dan program studi akuntansi Fakultas Ekonomi Universitas Negeri Yogyakarta. Setiap kelas dibagikan 4 jenis kasus secara acak (random), dan setiap subjek hanya mendapat satu jenis kasus. Sebelum subjek mengisi kasus, peneliti menjelaskan kewajiban subjek dalam ekperimen tersebut dan menjelaskan perintah-perintah yang ada dalam kasus tersebut secara jelas. Setelah peneliti menjelaskan, subjek dipersilahkan untuk mengisi kasus, dan setelah kasus semuanya telah diisi oleh subjek, kasus dikembalikan lagi kepada peneliti, serta subjek mendapat sedikit tanda terimakasih dari peneliti.

\section{Instrumen Pengumpulan Data}

Instrumen yang digunakan pada penelitian ini berbentuk kasus untuk variabel negative framing, adverse selection, dan adverse selection serta untuk variabel locus of control berbentuk pernyataan chek list. Untuk instrumen kasus diadopsi dari penelitian Dwita (2007), Andi (2009), dan Milka (2012), sedangkan untuk locus of control menggunakan work of locus of control scale (WLCS) yang dibuat oleh spector (1998).

\section{Teknik Analsisi Data}

Sebelum melakukan penelitian yang sebenarnya, peneliti melakukan pilot test kepada 32 subjek penelitian, hasilnya ratarata subjek penelitian telah mengerti dengan kasus yang diberikan.

Sebelum melakukan teknik analsis data, peneliti melakukan uji validitas dan reliabilitas, uji normalitas, serta uji homogenitas sebagai uji prasyarat penelitian ini.

Teknik analisis data yang digunakan untuk menguji hipotesis-hipotesis penelitian, adalah Univariate Analysis of Variance (ANOVA).

\section{HASIL PENELITIAN DAN PEMBAHASAN}

\section{Deskripsi Data Penelitian}

Data yang didapat setelah melakukan penelitian berjumlah 150 data subjek. Dari 150 data subjek tersebut, sejumlah 28 data subjek tidak lengkap pengisiannya dan tidak lolos chek manipulation, sehingga didapat data yang dapat dianalisis sejumlah 122 data subjek. Setelah dianalisis, ternyata data tersebut tidak berdistribusi normal, dan pada akhirnya peneliti hanya memakai sejumlah 


\section{JURNAL NOMINAL / VOLUME III NOMOR 1 / TAHUN 2014}

60 data subjek untuk melakukan analsis data.

\section{Hasil Pilot Test}

Pilot test dilakukan kepada 32 mahasiswa akuntansi angkatan 2010 fakultas ekonomi universitas negeri yogyakart. Hasil dari pilot test untuk kasus A, sebanyak 8 subjek semuanya telah paham dengan kasus yang diberikan. Dari 8 subjek, 7 subjek memilih melanjutkan proyek dan 1 subjek memilih menghentikan proyek, dengan rata-rata nilai evaluasi keputusan investasi sebesar 4,5.

Kasus B, sebanyak 6 subjek telah paham dengan kasus, dan hanya 1 subjek yang tidak paham dengan kasus yang diberikan. Dari 7 subjek, sebanyak 5 subjek memilih melanjutkan proyek dan 2 subjek memilih menghentikan proyek, dengan rata-rata nilai evaluasi keputusan investasi sebesar 4,14.

Kasus C, sebanyak 9 subjek telah paham dengan kasus yang diberikan. Dari 9 subjek, sebanyak 8 subjek memilih melanjutkan proyek, dan 1 subjek memilih menghentikan, dengan rata-rata nilai evaluasi keputusan investasi sebesar 4,5.

Kasus D, sebanyak 8 subjek telah paham dengan kasus yang diberikan. Dari 8 subjek, sebanyak 6 subjek memilih melanjutkan proyek, dan 1 subjek memilih menghentikan, dengan rata-rata nilai evaluasi keputusan sebesar 4,3.

\section{Statistik Deskriptif}

Statistik deskriptif variabel eskalasi komitmen nilai rata-ratanya sebesar 4,46. Nilai minimumnya sebesar 2 dan maksimumnya sebesar 6 dengan standar deviasi 1,294.

Statistik deskriptif variabel negative framing nilai rata-ratanya sebesar 0,50. Nilai minimumnya sebesar 0 dan maksimumnya sebesar 1 dengan standar deviasi 0,5042 .

Statistik deskriptif variabel adverse selection nilai rata-ratanya sebesar 0,50 . Nilai minimumnya sebesar 0 dan maksimumnya sebesar 1 dengan standar deviasi 0,5042 .

Statistik deskriptif variabel locus of control nilai rata-ratanya sebesar 0,58 . Nilai minimumnya sebesar 0 dan maksimumnya sebesar 1 dengan standar deviasi 0,4971.

Tabel 2. Statistik deskriptif

\begin{tabular}{|c|c|c|c|c|c|}
\hline Variabel & $\mathrm{N}$ & Min & Max & Mean & $\begin{array}{l}\text { Std. } \\
\text { Dev }\end{array}$ \\
\hline $\begin{array}{l}\text { Eskalasi } \\
\text { Komtmen }\end{array}$ & 60 & 2 & 6 & 4.46 & 1,29 \\
\hline $\begin{array}{l}\text { Negative } \\
\text { Framing }\end{array}$ & 60 & 0 & 1 & 0,50 & 0,50 \\
\hline $\begin{array}{l}\text { Adverse } \\
\text { Selection }\end{array}$ & 60 & 0 & 1 & 0,50 & 0,50 \\
\hline $\begin{array}{l}\text { Locus Of } \\
\text { Control }\end{array}$ & 60 & 0 & 1 & 0,58 & 0,49 \\
\hline
\end{tabular}




\section{Uji Hipotesis}

Uji hipotesis pada penelitian ini menggunakan teknik analisis two ways anova.

Dengan taraf signifikansi 5\%, hipotesis dikatakan dapat diterima apabila $\mathrm{P}_{\text {value }}$ signifikansi $\leq 0,05$, sedangkan hipotesis akan ditolak apabilai nilai $\mathrm{P}_{\text {value }}$ signifikansi $>0,05$.

Tabel 3. Uji Hipotesis

\begin{tabular}{lll}
\hline \multicolumn{1}{c}{ Variabel } & \multicolumn{1}{c}{ F } & \multicolumn{1}{c}{ Sig. } \\
\hline Neg. & 14,650 & 0,000 \\
Adv. & 14,547 & 0,000 \\
Neg.*Adv. & 14,810 & 0,000 \\
Neg.*LOC. & 0,009 & 0,926 \\
Adv.*LOC. & 0,548 & 0,462 \\
Neg.*Adv.*LOC. & 7,988 & 0,007 \\
Dependen Variabel: Eskalasi Komitmen
\end{tabular}

Sumber: Data diolah

Dari pengujian hipotesis 1 yaitu negative framing berpengaruh terhadap eskalasi komitmen pada tabel 3 di atas, dapat diketahui hasil pengujian yang didapat menunjukkan pengaruh yang signifikan sebesar $0,000 \quad(\mathrm{p} \leq 0,05)$. Hasil pengujian tersebut mampu membuktikan bahwa, ketika manajer menerima informasi yang diframing secara negatif dalam bentuk pilihan antara kerugian pasti yang telah terjadi dengan kerugian di masa mendatang yang belum pasti dari proyek investasi yang sedang ditanganinya, maka manajer tersebut cenderung lebih meningkatkan komitmennya dengan membuat keputusan melanjutkan proyek investasi yang tidak menguntungkan (eskalasi komitmen). Dengan memilih melanjutkan proyek, manajer memilih menambahkan dana pada proyek investasinya dan berharap mendapat pengembalian yang positif di masa mendatang. Hasil penelitian ini juga mendukung teori prospek yang menjelaskan bagaimana frame yang diadopsi sesorang manajer dapat mempengaruhi keputusan yang dibuatnya. Dalam hal ini ketika seorang manajer mendapat informasi yang di-framing secara negatif, maka keputusan yang dibuat oleh manajer tersebut akan cenderung melanjutkan proyek invetsasi yang tidak menguntungkan.

Hasil penelitian ini juga mendukung bahwa, teori prospek yang dikembangkan oleh Kahneman dan Tversky mampu menjelaskan bagaimana frame yang diadopsi sesorang manajer dapat mempengaruhi keputusan yang dibuatnya. Dalam hal ini ketika seorang manajer mendapat informasi yang di-framing secara negatif, maka keputusan yang dibuat oleh manajer tersebut akan cenderung melanjutkan proyek invetsasi yang tidak menguntungkan.

Dari pengujian hipotesis 2 yaitu adverse selection berpengaruh terhadap eskalasi 


\section{JURNAL NOMINAL / VOLUME III NOMOR 1 / TAHUN 2014}

komitmen pada tabel 3 di atas, dapat diketahui hasil pengujian yang didapat menunjukkan pengaruh yang signifikan sebesar 0,000 $(\mathrm{p} \leq 0,05)$. Hasil pengujian tersebut mampu membuktikan bahwa, seorang manajer yang memiliki informasi privat yang tidak diketahui orang lain dalam perusahaan ditambah dengan terdapat kesempatan untuk melalaikan tugas (incentive to shirk) bagi manajer (kondisi adverse selection), maka keputusan yang dibuat manajer cenderung melanjutkan proyek investasi yang tidak menguntungkan (eskalasi komitmen).

Hasil penelitian ini juga mendukung bahwa, kondisi eskalasi komitmen menurut teori agensi adalah adanya ketidakseimbangan informasi antara prinsipal dan agen (manajer) dengan ditambah adanya kesempatan untuk melalaikan tugas (incentive to shirk) bagi manajer (kodisi adverse selection).

Dari pengujian hipotesis 3 yaitu negative framing dan adverse selection secara bersama-sama berpengaruh terhadap eskalsi komitmen pada tabel 3 di atas, dapat diketahui hasil pengujian yang didapat menunjukkan pengaruh yang signifikan sebesar $0,000(\mathrm{p} \leq 0,05)$.

Hasil pengujian tersebut mampu membuktikan bahwa, suatu umpan balik negatif yang diterima oleh manajer atas proyek yang ditanganinya maka manajer akan melihat kemungkinan untuk menghentikan atau melanjutkan proyek investasi tersebut. Peran kondisi adverse selection di sini adalah ketika manajer tersebut memiliki informasi privat dan ada kesempatan untuk melalaikan tugas (incentive to shirk) bagi manajer tersebut, maka manajer tersebut akan cenderung mengejar kepentingannya sendiri dengan melanjutkan proyek yang tidak menguntungkan dan berharap mendapat mendapat pengembalian positif dimasa yang akan datang untuk memperbaiki kerugian diawal investasi proyeknya.

Dari pengujian hipotesis 4 yaitu locus of control memoderasi pengaruh negative framing terhadap eskalasi komitmen pada tabel 3 di atas, dapat diketahui hasil pengujian yang didapat menunjukkan locus of control tidak terbukti memoderasi pengaruh negative framing terhadap eskalasi komitmen. Hasil tersebut ditunjukkan dengan nilai signifikansi sebesar 0,926 $(\mathrm{p}>0,05)$.

Hasil pengujian tersebut tidak mampu membuktikan bahwa, ketika seorang manajer diberi informasi yang di-framing secara negatif atas proyek investasi yang sedang ditanganinya maka manajer tersebut cenderung meningkatkan komitmennya untuk membuat keputusan melanjutkan proyek investasi yang tidak menguntungkan. Peran tipe eksternal locus of control yang dimiliki manajer tersebut adalah tipe eksternal locus of control 


\section{JURNAL NOMINAL / VOLUME III NOMOR 1 / TAHUN 2014}

memiliki tingkat sensitivitas tinggi dan cenderung berhati-hati dalam mengambil sebuah keputusan, seharusnya tingkat eskalasi komitmen dapat diturunkan atau dikurangi. Tetapi hasil yang berbeda didapat pada penelitian ini. Hasil penelitian menunjukkan bahwa, manajer bertipe eksternal locus of control yang mendapatkan suatu informasi yang diframing secara negatif, manajer tersebut cenderung melanjutkan proyek investasi yang tidak menguntungkan, artinya tipe locus of control tidak terbukti menurunkan tingkat eskalasi komitmen.

Dari pengujian hipotesis 5 yaitu locus of control memoderasi pengaruh adverse selection terhadap eskalasi komitmen pada tabel 3 di atas, dapat diketahui hasil pengujian yang didapat menunjukkan locus of control tidak terbukti memoderasi pengaruh adverse selection terhadap eskalasi komitmen. Hasil tersebut dapat ditunjukkan dengan nilai signifikansi sebesar 0,462 ( $>>0,05)$.

Hasil pengujian tersebut tidak mampu membuktikan bahwa, ketika seorang manajer memiliki informasi privat yang tidak dimiliki orang lain dalam perusahaan dan terdapat kesempatan untuk melalaikan tugas (incentive to shirk) bagi manajer tersebut (kondisi adverse selection), maka manajer tersebut cenderung meningkatkan komitmennya untuk membuat keputusan melanjutkan proyek investasi yang tidak menguntungkan. Peran tipe eksternal locus of control yang dimiliki manajer tersebut adalah tipe eksternal locus of control memiliki tingkat sensitivitas tinggi dan cenderung berhati-hati dalam mengambil sebuah keputusan, seharusnya tingkat eskalasi komitmen dapat diturunkan atau dikurangi. Tetapi hasil yang berbeda didapat pada penelitian ini. Hasil penelitian menunjukkan bahwa, manager bertipe eksternal locus of control yang memiliki informasi privat yang tidak dimiliki orang lain dalam perusahaan dan terdapat kesempatan untuk melalaikan tugas (incentive to shirk) bagi manajer tersebut (kondisi adverse selection), manajer tersebut cenderung tetap melanjutkan proyek investasi yang tidak menguntungkan, artinya tipe eksternal locus of control tidak terbukti menurunkan tingkat eskalasi komitmen.

Dari pengujian hipotesis 6 yaitu locus of control memoderasi pengaruh negative framing dan adverse selection secara bersama-sama terhadap eskalasi komitmen pada tabel 3 di atas, dapat diketahui hasil pengujian yang didapat menunjukkan locus of control terbukti memoderasi pengaruh negative framing dan adverse selection secara bersama-sama terhadap eskalasi komitmen. Hasil tersebut dapat ditunjukkan dengan nilai signifikansi sebesar 0,007 $(\mathrm{p} \leq 0,05)$. 


\section{JURNAL NOMINAL / VOLUME III NOMOR 1 / TAHUN 2014}

Hasil pengujian tersebut mampu membuktikan bahwa, ketika seorang manajer mendapat suatu informasi yang diframing secara negatif atas proyek investasi yang sedang ditanganinya dan manajer tersebut memiliki informasi privat yang tidak dimiliki orang lain dalam perusahaan, serta terdapat kesempatan untuk melailaikan tugas (incentive to shirk) bagi manajer tersebut (kondisi adverse selection), maka manajer tersebut akan cenderung meningkatkan komitmennya untuk membuat keputusan melanjutkan proyek investasi yang tidak menguntungkan. Peran tipe eksternal locus of control yang dimiliki manajer tersebut adalah tipe eksternal locus of control memiliki tingkat sensitivitas tinggi dan cenderung berhati-hati dalam mengambil sebuah keputusan, seharusnya tingkat eskalasi komitmen dapat diturunkan atau dikurangi. Hasil yang sama didapat pada penelitian ini. Hasil penelitian menunjukkan bahwa, manajer bertipe eksternal locus of control yang memiliki informasi privat yang tidak dimiliki orang lain dalam perusahaan dan terdapat kesempatan untuk melalaikan tugas (incentive to shirk) bagi manajer tersebut (kondisi adverse selection), manajer tersebut cenderung menghentikan proyek investasi yang tidak menguntungkan, artinya tipe locus of control terbukti menurunkan tingkat eskalasi komitmen.

\section{SIMPULAN DAN SARAN}

Berdasarkan hasil analisis dan pembahasan diatas, maka dapat disimpulkan sebagai berikut:

a) Negative framing berpengaruh terhadap eskalasi komitmen. Manager yang mendapat perlakuan negative framing cenderung memilih melanjutkan proyek investasi daripada manager yang mendapat perlakuan tanpa negative framing.

b) Adverse selection berpengaruh terhadap eskalasi komitmen. Manager yang mendapat perlakuan adverse selection cenderung memilih melanjutkan proyek investasi daripada manager yang mendapat perlakuan tanpa adverse selection.

c) Negative framing dan adverse selection secara bersama-sama berpengaruh terhadap eskalasi komitmen. Manager yang mendapat perlakuan negative framing dan adverse selection cenderung memilih melanjutkan proyek investasi daripada manager yang mendapat perlakuan tanpa negative framing dan adverse selection.

d) Locus of control tidak memoderasi pengaruh negative framing terhadap eskalasi komitmen. Manager yang bertipe eksternal locus of control yang mendapat perlakuan negative framing, manager tersebut cenderung memilih melanjutkan proyek. Jadi, tipe eksternal 


\section{JURNAL NOMINAL / VOLUME III NOMOR 1 / TAHUN 2014}

locus of control tidak terbukti menurunkan eskalasi komitmen ketika mendapat perlakuan negative framing dan hal ini sama saja dengan tipe internal locus of control diperlakukan dengan hal yang sama.

e) Locus of control tidak memoderasi pengaruh adverse selection terhadap eskalasi komitmen. Manager yang bertipe eksternal locus of control yang mendapat perlakuan adverse selection, manager tersebut cenderung memilih melanjutkan proyek. Jadi, tipe eksternal locus of control tidak terbukti menurunkan eskalasi komitmen ketika mendapat perlakuan adverse selection dan hal ini sama saja dengan tipe internal locus of control diperlakukan dengan hal yang sama.

f) Locus of control memoderasi pengaruh negative framing dan adverse selection secara bersama-sama terhadap eskalasi komitmen. Manager yang bertipe eksternal locus of control yang mendapat perlakuan negative framing dan adverse selection, manager tersebut cenderung memilih melanjutkan proyek. Jadi, tipe eksternal locus of control terbukti menurunkan eskalasi komitmen ketika mendapat perlakuan negative framing dan adverse selection daripada tipe internal locus of control diperlakukan dengan hal yang sama.
Penelitian ini memiliki beberapa keterbatasan sebagai berikut:

a) Pemilihan mahasiswa sebagai pengganti manager dapat menimbulkan bias penelitian karena mahasiswa cenderung acuh atau tidak serius pada saat dilakukan penelitian eksperimen.

b) Dalam menyampaikan treatment dalam kasus yang diberikan, dapat menimbulkan perbedaan persepsi dan pemahaman oleh mahasiswa.

c) Perbedaan hasil ujian variabel locus of control kemungkinan dipengerahui oleh cara adopsi kuesioner yang salah dan pada khirnya mahasiswa kurang paham isi kuesionernya.

\section{DAFTAR PUSTAKA}

Adisaputro Gunawan. (1997). Anggaran Perusahaan 2. Edisi 1. Yogyakarta: BPFE-Yogyakarta.

Andi Irfan. (2009). "Pengaruh Locus of Control Terhadap Hubungan Antara Justice dan Tingkat Eskalasi Komitmen Dalam Penganggaran Modal." Tesis tidak diterbitkan. PPs UGM.

Gendro Wiyono. (2011). Merancang Penelitian Bisnis dengan Alat Analisis SPSS \& Smart PLS. Yogyakarta: UPP STIM YKPN.

Partino \& Idrus. (2009). Statistik Deskriptif. Yogyakarta: Safiria Insania Press 
Sekaran, Uma. (2006). Reasearch Methods For Business jilid 2. Edisi 4. Jakarta: Salemba Empat.

Tri Koroy Ramaraya. (2008). "Pengujian Efek Pembingkaian Sebagai Determinan Eskalasi Komitmen Dalam Keputusan Investasi; Dampak Dari Pengalaman Kerja." Simposium Nasional Akuntansi 11. Hal: 1-26. 